\title{
Problem-based learning approaches in meteorology
}

Article

Accepted Version

Open Access after 1 yr embargo

Charlton-Perez, A. (2013) Problem-based learning approaches in meteorology. Journal of Geoscience Education, 61 (1). pp. 12-19. ISSN 1089-9995 doi: https://doi.org/10.5408/11-281.1 Available at https://centaur.reading.ac.uk/34206/

It is advisable to refer to the publisher's version if you intend to cite from the work. See Guidance on citing.

Published version at: http://dx.doi.org/10.5408/11-281.1

To link to this article DOI: http://dx.doi.org/10.5408/11-281.1

Publisher: The National Association of Geoscience Teachers

All outputs in CentAUR are protected by Intellectual Property Rights law, including copyright law. Copyright and IPR is retained by the creators or other copyright holders. Terms and conditions for use of this material are defined in the End User Agreement.

\section{www.reading.ac.uk/centaur}

\section{CentAUR}

Central Archive at the University of Reading

Reading's research outputs online 


\section{Problem Based Learning approaches in Meteorology}

\section{Abstract}

3 Problem Based Learning, despite recent controversies about its effectiveness, is used

4 extensively as a teaching method throughout higher education. In Meteorology, there has

5 been little attempt to incorporate Problem Based Learning techniques into the curriculum.

6 Motivated by a desire to enhance the reflective engagement of students within a current

7 field course module, this project describes the implementation of two test Problem Based

8 Learning activities and testing and improvement using several different and

9 complementary means of evaluation. By the end of a two-year program of design,

10 implementation, testing and reflection/re-evaluation two robust, engaging activities have

11 been developed which provide an enhanced and diverse learning environment on the field

12 course. The results suggest that Problem Based Learning techniques would be a useful

13 addition to the Meteorology curriculum and suggestions for courses and activities which

14 may benefit from this approach are included in the conclusions. 


\section{Introducing the problem and existing course design}

16 This study assesses both the feasibility and usefulness of Problem Based Learning (PBL)

17 approaches in Meteorology teaching. It aims to discover, by means of a controlled and

18 evaluated test implementation, if PBL could play a role in Meteorology teaching at undergraduate and masters level in UK Universities. Two new PBL activities are introduced to an existing fieldwork based Meteorology module. The activities are both designed in line with best practice guidelines for PBL but are designed to be sufficiently different that conclusions about the overall suitability of PBL for Meteorological teaching can be drawn. The success of the new activities is evaluated using a combination of student feedback, peer observation, analysis of resulting student outputs and personal reflection.

1.1 The problem - passive engagement of students

Meteorology as a subject has a strong practical, experimental component. Teaching students how to make effective measurements and how to use the data collected appropriately is a key part of the undergraduate curriculum, which also provides a strong transferable skill. Although a large element of practical work is included in the University of

31 Reading's Meteorology and Climate BSc and MMet programs, in its current form much of this teaching follows a relatively traditional model of several self-contained experiments with well defined expected outcomes known by staff prior to students conducting the experiments. While this approach has value, it fails to allow students to address key components of the most widely held view of experiential learning, the Kolb learning cycle (Kolb, 1984).

37 [Figure 1 about here] 
PBL is an approach to teaching and learning that forms part of a broader spectrum of

40

41

42

43

44

techniques known as inquiry based learning. Inquiry based learning can be broadly defined to have the following characteristics (Kahn and O'Rouke, 2004)

- Engagement with a complex situation or scenario that is sufficiently open ended to allow a variety of responses or solutions

- Students direct the lines of inquiry and the methods employed

- The inquiry requires students to draw on existing knowledge and to identify their required learning needs

- Tasks stimulate curiosity in the students, encouraging them to actively explore and seek out new evidence

- Responsibility falls to the student for analyzing and presenting that evidence in appropriate ways and in support of their own response to the problem.

PBL in particular involves students addressing a problem in a small group and defining the further knowledge and investigation that they require to solve the problem. In many ways PBL is as much about identifying the key unknowns in a problem and appropriate ways to tackle these problems as it is about solving the problem at hand. The PBL approach to learning does not require students to have mastered a body of knowledge before the completion of a project (as in a typical undergraduate or masters dissertation) but allows the understanding of the student and their ability to solve the problem to evolve together.

\subsubsection{Broad advantages and disadvantages}

Kahn and O'Rourke (2004) list a large number of potential advantages of PBL as a teaching style particularly associated with student motivation and engagement and employability. As they identify “...the modern "knowledge economy" places a premium on the ability to create relevant knowledge that helps to solve specific problems..." PBL provides a way of encouraging students to participate in constructive, experiential learning, as in the Kolb learning cycle (Fig. 1). This happens by encouraging students to 
engage in active experimentation to test their ideas and then use their experience of the outcomes of their experimentation to reflect on their grasp of the knowledge at hand. This reflective element is particularly important and can be enhanced in the PBL model by the chance for students to contrast their own performance and knowledge with that of their peers.

Despite these widely accepted benefits of PBL in the educational literature, there is current controversy over the effectiveness of minimally guided techniques in general. This controversy links to the paper of Kirschner, Sweller and Clark (2006, KSC06) who make the case that minimally directed techniques are incompatible with our knowledge of human cognitive architecture (in particular the Atkinson and Shiffrin (1968) sensory memoryworking memory-long-term memory model). KSC06 argue that since the capacity of working memory is limited, placing heavy demands on it by requiring problem-based searching should be avoided. KSC06 also state that numerous studies have suggested that a more directed learning approach, particularly incorporating numerous 'workedexamples' is a more efficient use of novice and intermediate learner's cognitive resources. Several responses to KSC06 exist in the literature (Schmidt et al. (2007), Hmelo-Silver et al. (2007), Kuhn (2007)) along with a commentary on these responses by the original authors of KSC06 (Sweller et al. (2007)). Common to this discussion is the idea that PBL techniques without any guidance are inferior to those with some strong scaffolding provided by the course leader. They also agree that much more careful research with properly controlled experiments is required to fully assess the advantages and disadvantages of different educational techniques. In practical terms, much of the discussion of the advantages and disadvantages of minimally guided techniques is focused on rather fundamentalist positions of fully guided or fully unguided teaching. In reality, any implementation of PBL in Meteorology is likely to exist somewhere between these extremes with some guidance provided by course tutors. 
91 It should also be recognized, however, that PBL techniques may be more appropriate for

92 intermediate and advanced learners and hence for courses at the end of undergraduate

93 programs and at masters level. The reason for this is two-fold. Firstly, to be delivered in a

94 time-efficient manner PBL requires students to have a relatively mature set of study skills

95 (which they develop during the early undergraduate years). Secondly, PBL in Meteorology

96 requires students to have a firm background in the physics and chemistry of the

97 atmosphere so that they can ask and answer questions appropriate to problem at hand.

98 Despite the controversy about PBL techniques in the literature it seems appropriate to

99 investigate their usefulness in the Meteorological context, provided that this is within a

100 course with a range of different instructional techniques including directed learning. In this

101 way PBL techniques can be evaluated but at low potential detriment to students involved

102 in the course if they prove to be of limited value.

$103 \quad$ 1.2.2 Implementation in higher education and in Meteorology

104 Various reviews of the implementation of PBL approaches in higher education exist in the 105 literature (e.g. Boud and Feletti, 1997, Savin-Baden 2000). Even a cursory glance at these 106 texts reveals three things about the implementation of PBL in higher education:

107 PBL has been used to refer to a broad range of educational activities from the design of

108 an individual element of a problem class to the design of a full three-year curriculum.

109 - The implementation of PBL varies greatly between different subjects. Those with a strong 110 element of practical problem solving (e.g. Medicine and Law) have been by far the most 111 enthusiastic adopters of PBL.

112 - A barrier to the implementation of PBL more widely is the lack of understanding amongst 113 academic staff on their role within a PBL exercise.

114 There has been little implementation of PBL techniques in Meteorology or in related Earth 115 and Environmental science fields. Some literature on the implementation of PBL in GEES 116 subjects is available in a special edition of Planet 
117 (http://www.gees.ac.uk/planet/index.htm\#). Of the articles in this issue, the most relevant is

118 that which describes the implementation of PBL on a field course module by Perkins et al.

119 A particularly interesting aspect of this article is the adoption of the 'Seven-Jump'

120 Maastricht model for PBL tutorials (Gijselaers, 1995). This provides a framework model for

121 tutorial structure for PBL activities that is adopted in the two new activities introduced in

122 section 3 (with some modification for activities which take place entirely on Arran). This

123 model characterizes PBL learning as a series of seven 'jumps':

124 [Table 1 about here]

125 Perkins et al. report that PBL had a generally positive impact on the field activities and was

126 equally at home in 'hard-science' subjects (although as above, clear tutor guidance was a

127 key factor in its success). One major difference between our own field course and that of

128 Perkins et al. is the length of preparatory time, which is long (16 hours) in the case of

129 Perkins et al. and relatively short in our case (1 hour). Although the short preparatory time

130 was necessary in our case because the course is shared between two Universities with no

131 chance to arrange preparatory classes, this should note be viewed as a disadvantage. In

132 fact the time-limited nature of the preparatory work is in many ways a more faithful

133 simulation of real meteorological field work where planning of experiments is often done at

134 short-notice because of experimental and operational constraints.

1351.3 Test module - Atmospheric Science field course

136 The module chosen to test the implementation of PBL approaches in Meteorology is an

137 atmospheric science field course jointly taught with colleagues from the University of

138 Leeds. The course is residential and takes place over 8 days based at a field centre on the 139 Isle of Arran. Typically there are around 35 students on the course, split 50:50 between

140 students from Reading and Leeds. The course is offered at both third year undergraduate

141 and masters level. The background of students on the course is diverse; with a wide range

142 of mathematical skill in particular a major challenge. Activities on the course are primarily 
143 field based and include an all day hike to the top of Goat Fell ( $850 \mathrm{~m})$ taking

144 measurements on the way. The traditional approach to practical experimental learning

145 adopted in Meteorology incorporates only the active experimentation and concrete

146 experience stages of the Kolb learning cycle. On this field course, students have the

147 opportunity to participate in several different experiments at once, allowing them the

148 opportunity to try to piece abstract concepts about the atmosphere together. However, a

149 remaining problem on the course is that all the experiments have been designed by the

150 staff participating to have relatively simple outcomes, known at the outset by staff (and

151 sometimes students). Therefore, the reflective observation link in the Kolb learning cycle

152 chain is often opaque or broken, making it difficult for the students to move to higher-level

153 abstract conceptualization.

1541.4 Assessment of current course design

155 To fully examine the current structure of the course and the way that its current structure

156 maps to the Kolb learning cycle a course map (Conole, 2010) was completed. Mapping the

157 course in this way provides a concise summary of its current state and highlights the

158 issues discussed in the previous section. Since the test module is made up of a series of

159 discrete activities, it has also been possible to map these activities to the Kolb learning

160 cycle. A video diary describing the initial mapping of the course and the problem at hand

161 can be found at: http://cloudworks.ac.uk/cloud/view/3813. By mapping the course

162 additional issues associated with the course were highlighted or emphasized:

163 - The lack of opportunity for reflection in the course is clear, only one of the seven

164 activities provides a way for students to examine their own work or put it in the context of

165 others work. As a consequence many of the activities 'short-circuit' the Kolb learning cycle.

166 - Along with this lack of reflective elements, no opportunity is provided to the students for

167 formative feedback on their work. While the high staff-student ratio on the course does

168 allow staff to informally have a dialogue with students to improve their understanding, 
169 there is no way for students to gain feedback on their written work, which is in some ways

170 a more concrete demonstration of their understanding.

\section{2. Test changes to module}

$172 \quad 2.1$ Two new PBL elements

173 With the key messages of the proceeding literature in mind, two similar but different PBL

174 approaches were introduced into the atmospheric science field course module. The first of

175 these PBL activities involved students on both the BSc and MMet programs and students

176 from our partner the University of Leeds. It focused on trying to address issues of missing

177 stages in the Kolb learning cycle outlined above. The second activity involved only

178 University of Reading students on the MMet program and was completed over a longer

179 period upon return to Reading. The aim of this activity was to provide a second M-level

180 route to obtaining appropriate professional skills in environmental monitoring. Example

181 course materials for each of the new activities are provided on-line at:

182 http://www.met.reading.ac.uk/ sws05ajc/teaching/pbl.html

183 2.2 PBL Activity I - Ozonesonde launch

184 This activity involved the design of an experiment to launch an ozonesonde, a piece of 185 equipment attached to a weather balloon, which measures ozone concentrations

186 throughout the atmosphere. Students were already part of mixed University of

187 Reading/University of Leeds teams for other activities. The students were told that there

188 were only enough resources to launch a single ozonesonde and that they should design

189 an experiment to maximize the benefit of observations from a single launch.

190 The activity proceeded as follows:

191 - The activity was introduced in a short lecture and through course documents. Some

192 information about ozone in the atmosphere was given along with some technical details

193 about the equipment available for use. 
- Students discussed how and when to launch the ozonesonde in their teams. They had access both to staff (as facilitators) and forecast information about future weather conditions to determine when an interesting time to launch would be (initial abstract conceptualization phase).

- Students were asked to write a short work plan for the launch. The work plan was requested to be in the form of a mock grant proposal to a fictional funding agency so that the process provided as close a simulation of real scientific practice as possible. The proposals were then presented to a steering committee of staff that assessed which of the proposals to take forward (active experimentation phase).

- The ozonesonde was launched according to the instructions of the successful bid and data provided to all of the groups to analyze. (second part active experimentation phase). - Following the launch students analyzed both the data produced by the experiment and also the differences between the winning bid and their own. They were asked to comment on the differences between their bid and the winning bid and identify any deficiencies of either bid based on the results of the experiment. This part required the students to enter the reflective phase, based on the experimental design and to build this reflection back into their original abstract conceptualization.

\subsection{PBL Activity II - Climate monitoring station design}

This activity took place following the return of students on the MMet program from Arran and continued throughout the following autumn term. Students were given the problem of designing a new climate monitoring station for Arran based both on their experience of the field course location and meteorology and further original research from existing literature. The module convener and two members of research staff facilitated the activity in three one-hour discussion sessions. Students were asked to produce a 15-page design specification for the climate monitoring station detailing equipment used, fit to national and international monitoring priorities and operating procedure. The first task for the students 
220

221

222

223

224

225

226

227

228

229

230

231

232

233

234

235

236

237

238

239

240

241

242

243

244

245

was to decide on the priorities for the climate monitoring based on their own analysis of the literature and discussion in a group forum. The activity specifically targets the reflective observation and abstract conceptualization elements of the Kolb learning cycle, whilst using the observational experience gained on Arran as the active experimentation and concrete experience phases. The final assessment of the design specification emphasized these aspects.

\section{Method of implementation and assessment}

Design of the new PBL methods took place during academic year 2008/9 and was introduced into the course in Autumn 2009. A second test implementation was then repeated with some modification in Autumn 2010.

\subsection{Evaluation methods}

With any new teaching and learning activity a crucial part of its successful introduction is a robust evaluation (Fry, Ketteridge and Marshall, 2008). Project evaluation was conducted using a range of techniques including student feedback, peer observation, analysis of resulting student outputs and personal reflection. Student feedback was obtained through a carefully designed diagnostic questionnaire (Gibbs, Habeshaw and Habeshaw, 1988) that specifically explored the distinctions between the PBL approach and more traditional approaches used for the majority of the field course. A similar diagnostic questionnaire was applied to both activities and some questions were added to the questionnaire for activity II to explore the differences between the two activities. Peer observation from other staff was easily implemented since both activities took place within a staff intensive environment. Feedback was obtained through a separate diagnostic questionnaire and through unstructured interviews with colleagues. Again the emphasis was on which aspects of the PBL approach work well within a meteorological context. The interviews were used to check that answers to the questionnaires were truly diagnostic, providing an independent check of the methodology. The third stream of evaluation was through 
examination of student outputs for each activity and personal reflection from this

247 perspective. It was clear that the reflective element of the activities was well incorporated

248 since all students provided some reflection on their own and others work.

\section{4. Results from implementation in 2009}

250 The two activities were first implemented as part of the course during academic year

$2512009 / 10$. The course took place between 4th and 11th September on the Isle of Arran. 32

252 students took part in the course, 16 from Reading and 16 from Leeds. Of those students, 3

253 from Reading took the course at the masters level and also participated in the observing

254 system design activity during the autumn term 2009/10. The average mark for the course

255 overall was $63 \%$ with a standard deviation of $5 \%$. The ozonesonde activity had an average

256 mark of $64 \%$ with a standard deviation of $10 \%$. The observing system design activity had

257 an average mark of $62 \%$ (no standard deviation is recorded since only three students

258 participated). Raw results of the questionnaire are presented in Table 2.

259 [Table 2 about here]

2604.1 Reflection on student feedback

261 In general both activities were well received by the students who assessed generally high

262 grades in most categories. The questions can be usefully divided up into four broad

263 categories on which to assess the success of the PBL implementation. The first set of

264 questions assessed how well the activity was structured and communicated to students.

265 Clearly the small group of students who took part in the observing system activity did not

266 fully understand their task and this might have reduced their motivation in taking part.

267 There was an interesting discrepancy between the perception of the ozonesonde activity

268 as a good simulation of a real world task between the students (who generally thought it

269 was) and the staff (who had a mixed reaction). This was a positive outcome since it

270 suggested that the task was simpler than a complex real-world grant proposal but that this

271 did not detract from its appeal to the students. In all activities both staff and students 
272 judged the students to engage well with the reflective part of the activity that is a key part

273 of the Kolb cycle and crucial to this new activity. Interestingly, the extent to which the

274 students and staff believed that the reflection helped the students improve their

275 understanding was more mixed.

276 The second set of questions considered how students gained the required information for

277 the task. Answers showed the expected split between the two activities, students taking 278 part in the ozonesonde activity obtained most of the required information in written form 279 while students taking part in the observing system activity conducted their own research 280 and engaged with staff. When assessing how staff were used, students were generally 281 more pessimistic about their own input and claimed staff influenced both their subject 282 specific and generic skills more than the staff perceive. This is perhaps to be expected, but 283 it was important for the success of the activity that the students believed that their input 284 and decisions influenced the direction of both projects. The results identified that it should 285 be emphasized to staff that they act as facilitators of the discussion since part of the PBL 286 learning process is shaping and refining the problem at hand.

287 The third set of questions deals with the assessment of the activity upon completion by 288 both groups. As mentioned above, both staff and students were somewhat mixed in their 289 assessment of the utility of the reflective elements of the activities. Interestingly, students 290 believed that the comparison with other groups was a very helpful part of the ozonesonde 291 activity, whereas staff were more circumspect. In general the projects scored well amongst 292 all groups in their ability to improve both generic and specific skills.

293 Finally, the group of students who participated in both the ozonesonde and observing 294 system activities were asked to compare them. Interestingly for broader applications of 295 PBL there was a clear preference for the time-limited ozonesonde activity and the focus 296 that this brought to discussion. However in general the students believed the observing 
297 system activity to be at a higher educational level, which again fits well with the course

298 design.

299 Participants were also asked to make specific and general comments on the activities.

300 Few comments were received, but some of the most interesting were:

301 Student

302 "I didn't have much of an idea of what I was supposed to be doing or how to get a good 303 mark in this."

304 "Good but should only be done sometimes."

305 "Encourages time keeping."

306 "Makes you think more for yourself which encourages learning."

307 "I prefer more lecture based teaching, not a fan of large research projects stuff. It is 308 important it is more real-world, but $40 \%$ is still too heavy a weighting."

309 "Initial knowledge of the area needs to be taught first to better be able to do these 310 activities, but it challenges you to think about stuff in a more realistic context which is 311 good."

312 "It encourages you to think for yourself more. Although I didn't like it to begin with it has 313 taught me a lot."

314 Staff

315 "Encourages vibrant interaction between staff/student so that ideas are created and 316 developed quickly. Allowed for quickly working through problems and assimilation of 317 scientific knowledge."

318 "Good activity, although students found assessment of the speaking part a bit vague."

319 "You cover a lot less content but it may be more effective and the student learns a lot more 320 from it by making mistakes and learning/developing things by himself. Combined with 321 traditional approaches to teach the basics I think it is highly useful." 
323 Informal consultation with colleagues revealed that both activities had been well received

324 in the first instance and had enabled students to be more actively engaged in their learning

325 and to explore different facets of both problems than they might otherwise have done. The

326 major discussion point for the ozonesonde activity was the lack of training of staff both for

327 the PBL process and in the specifics of the activity itself. There was particular concern

328 about the role that the reflective activity should play. The major discussion point for the

329 observing system activity was the lack of engagement between students and staff

330 members outside contact hours. Both staff members felt that the students were disinclined

331 to ask for help and expertise even though this was explicitly offered.

3324.3 Consistency of evaluation using all three evaluation methods

333 A coherent picture of the successes and failures of the activities in their first

334 implementation arose from consideration of all three methods of evaluation. In general,

335 staff and students found the activity to be worthwhile and both in the questionnaire

336 evaluation and the informal interviews thought that the PBL approach promoted active

337 engagement amongst the students. Evaluation of student work, informal staff interviews

338 and the questionnaire responses highlighted the problems in the introduction of the

339 reflective elements, particularly in relation to the way in which staff participated in the

340 activity. There were however, some elements in which the different evaluation techniques

341 give different pictures of the activities. Although the survey results suggested students

342 didn't fully understand the purpose of the observing system activity the student outputs

343 (both in terms of a qualitative or quantitative evaluation) did not suggest that they

344 performed any better or worse than in the ozonesonde activity or in the course in general.

345 4.4 Changes made to activities

346 Identified actions to improve the activity for 2010 were:

347 - Improving the documentation and introduction of the observing system task for 2010. 
- Re-considering the reflective part of the ozonesonde activity to ensure it boosts student

349 understanding.

350 - Re-iterating to staff that their role should be advisory only

351 - Adding informal contact periods ('office hours') to the observing system activity to 352 encourage informal contact between staff and students.

353 These actions were undertaken during academic year 2010 and modified activities were 354 introduced into the course in September 2010.

\section{5. Results from implementation in 2010}

356 The second implementation of the two activities occurred as part of the course during 357 academic year 2010/11. The course took place between 5th and 12th September on the 358 Isle of Arran. 35 students took part in the course, 12 from Reading and 17 from Leeds. Of

359 those students, 5 from Reading took the course at the masters level and also participated 360 in the observing system design activity during the following autumn term. The average 361 mark for the course overall was $61 \%$ with a standard deviation of $4 \%$. The ozonesonde 362 activity had an average mark of $56 \%$ with a standard deviation of $4 \%$. It should be noted 363 that a different academic colleague at Leeds was responsible for marking the ozonesonde 364 activity in each year of the course. While every effort is made to standardize marking, 365 experience in previous years shows that the lower mark in the 2010 implementation is partly related to this change in marker. The observing system design activity had an

367 average mark of $65 \%$ with a standard deviation of $7 \%$.

3685.1 Reflection on improvement to PBL activities in second year of implementation

369 [Table 3 about here]

370 Results from the evaluation of the PBL activity in the second year of implementation were 371 extremely positive. In most cases where the evaluation of the 2009 module revealed that 372 the activity had been successful this positive result was maintained. In the areas where the 
3732009 evaluation identified improvements could be made the changes made to the PBL

374 procedure generally improved both student and staff evaluations, specifically:

375 - The improved documentation and introductory lectures incorporated into the observing

376 system activity significantly improved scores in the first part of the survey, particularly for

377 students showing that they understood the task better, were able to quickly focus on the

378 task at hand, that they felt that the task was a reasonable simulation of a real-world activity

379 and that they engaged strongly with the reflective activity.

380 - The improved oral description and staff training for the reflective part of the ozonesonde

381 activity significantly improved the scores of both staff and students in this part of the

382 survey. Particularly interesting was the gain in the mark for subject specific skills for both

383 staff and students.

384 Another interesting result of the second evaluation, perhaps related to the small sample

385 size and variation between student groups was the lack of preference for the time

386 constrained, ozonesonde activity in the 2010 cohort. While there was a strong preference

387 for this activity in the 2009 cohort, the 2010 cohort was enthusiastic about the observing

388 system activity, but expressed no clear preference for this PBL style as opposed to the

389 more limited, focused ozonesonde activity.

390 The 2010 control cohort who participated in both PBL activities also produced a number of

391 interesting comments and suggestions on PBL in general:

392 “...applying what you learn to a 'real-life' situation focuses one's mind and gives the

393 learning/research , etc., a full purpose..."

394 "I thought it was a very good way to go, in that we got the benefit of people which much

395 more expertise. Also it was done in a relaxed way which was good."

396 They also had some interesting thoughts on how PBL might be applied more generally in

397 their degree program:

398 "In Meteorology, it would be good to have more of this form of teaching..." 
“...to do it justice, it should come at a time where other deadlines are not imminent."

400 "Maybe with the final project a little more."

401 Staff comments highlighted that this approach was only really successful with outgoing

402 and able students (a comparison between the two cohorts participating in the observing

403 system activity was quite revealing). The second cohort, which was generally of higher

404 background ability engaged fully with the exercise and were more content with its learning 405 objectives and had overall better performance.

406 6. Conclusions and discussion

407 In conclusion, the test implementation of PBL approaches in Meteorology have proved to

408 be very successful and have provided useful new content for an existing course in an

409 innovative style unfamiliar to students. In general, students enjoyed the freedom given to

410 them by this approach and felt that it was a reasonably faithful simulation of a real-world

411 activity thereby improving their motivation for the task in question.

412 We plan to continue the experiment in future years and to seek to refine the methodology

413 used to improve its implementation. One idea for the ozonesonde activity would be to

414 switch the science experiment in question to one with more potential outcomes and

415 experimental strategies to improve the diversity of student responses and observed

416 features. Nonetheless, clearly the PBL methodology has an important part to play in the

417 module, coupled with other teaching approaches.

418 More generally, it is clear there is a role for PBL teaching within Meteorology as a

419 complement to existing teaching styles. It would be difficult, however, to advocate moving

420 to a whole curriculum PBL or EBL style for Meteorology teaching in higher education as is

421 done in some disciplines and institutions (particularly in the medical sciences). Since

422 Meteorology represents somewhat of a departure for most students from their previous

423 background knowledge and general approach to learning, a full PBL curriculum would not 
424 be able to provide the required breadth and depth of material that students require,

425 particularly in their first two years of higher education.

426 The experience of implementing PBL in a Meteorological context emphasizes that the key

427 gain is in the real-world simulation aspect and its affect on student motivation. Successful

428 implementation of a PBL activity within Meteorology would require careful thinking about

429 the kind of activity that could be introduced, if students had significant training and maturity

430 to deal with this kind of learning and the production of carefully design resources that

431 provided adequate but not too comprehensive background material for the students. As

432 was evident from staff responses, there is also a clear need to educate staff involved in the

433 activity about the limits and purpose of their role in the activity and the module convener

434 should consider how best to do this in conjunction with designing the activity.

435 There are some clear benefits to a limited amount of PBL teaching that could be

436 incorporated into other parts of the Meteorology curriculum. For most Meteorology

437 programs, there are a few obvious candidates for small tests of PBL to see if the lessons

438 learnt in this project transfer to other study topics. In particular, topics with a strong public

439 policy impact such as climate change could benefit from PBL activities that simulate the

440 real-world questions asked of scientists by governments and large corporations.

441 Additionally, in many institutions final year students complete a fairly traditional honors

442 project with project topics and resources supplied by members of academic staff.

443 Incorporating a PBL design and some element of peer-review may better prepare students

444 for the workplace in both academic and non-academic environments by providing a

445 simulation of the practice of real-world scientific research.

446 Acknowledgements

447 This project could not have been completed without the help and support of a number of

448 academic colleagues at the Universities of Leeds and Reading who participated in the field

449 course and the PBL activities described. I would like to thank Peter Knippertz, Jim 
451 Bohnenstengel, Julien Delanoe, Ellie Highwood, Dan Kirshbaum, John Nicol \& Curtis

452 Wood at the University of Reading. Special thanks are given to Mat Evans (Leeds, now at

453 the University of York) who co-wrote the ozonesonde activity. This project was carried out

454 as part of the University of Reading, Postgraduate Certificate in Academic Practice

455 program for new academics and was carried out under the supervision of Nina Brooke

456 who made valuable comments that improved the project and manuscript.

\section{References}

458 Atkinson, R., \& Shiffrin, R., 1968. Human memory: A proposed system and its control

459 processes. In K. Spence \& J. Spence (Eds.), The psychology of learning and motivation.

460 New York, Academic.

461 Carnduff J. \& Reid N., 2003. Enhancing Undergraduate Chemistry Laboratories. London,

462 Royal Society of Chemistry.

463 Conole G., 2010. http://cloudworks.ac.uk/cloud/view/2971

464 Boud D. \& Feletti G., 1997. The Challenge of Problem-Based learning. London, Kogan

465 Page

466 Fry H., Ketteridge S. \& Marshall S., 2008. A Handbook for Teaching and Learning in

467 Higher Education. New York, Routledge.

468 Gibbs G., Habeshaw S. \& Habeshaw T., 1988. 53 Interesting Ways to Appraise your

469 Teaching. Bristol, Technical and Education Services.

470 Gijselaers, W., 1995. Perspectives on problem-based learning in Gijselaers, W,

471 Tempelaar, D, Keizer, P, Blommaert, J, Bernard, E \& Kapser, H (eds) Educational

472 Innovation in Economics and Business Administration: The Case of Problem-

473 Based Learning. Dordrecht, Kluwer. 
474 Hmelo-Silver C., Golan-Duncan R. \& Chinn C. A., 2007. Educational Psychologist:

475 Scaffolding and Achievement in Problem-Based and Inquiry Learning: A Response to

476 Kirschner, Sweller and Clark., 42, 99-107

477 Kahn P. \& O' Rourke K., 2004. Guide to Curriculum Design: Enquiry Based Learning, UK

478 Higher Education Academy.

479 Kirschner, P.A., Sweller, J. \& Clark, R.E., 2006. Educational Psychologist: Why minimal

480 guidance during instruction does not work: An analysis of the failure of constructivist,

481 discovery, problem-based, experiential, and inquiry based teaching. 41, 75-86.

482 Kolb, D.A., 1984. Experiential Learning. New Jersey, Prentice-Hall.

483 Kuhn, D., 2007. Educational Psychologist: Is direct instruction the answer to the right

484 question?, 42, 109-113.

485 Perkins C., Evans M., Gavin H., Johns J. \& Moore J., 2007. Fieldwork and PBL.

486 http://www.gees.ac.uk/planet/index.htm\#PSE2

487 Savin-Baden M., 2000. Problem-Based Learning in Higher Education: Untold Stories,

488 Buckingham, Open University Press

489 Schmidt H. G., Loyens S. M. M., van Gog T. \& Paas F., 2007. Educational Psychologist:

490 Problem-Based Learning is Compatible with Human Cognitive Architecture: Commentary

491 on Kirschner, Sweller and Clark, 2006. 42, 91-97

492 Sweller J., Kirschner P. A. \& Clark R. E., 2007. Educational Psychologist: Why Minimally

493 Guided Teaching Techniques Do Not Work: A Reply to Commentaries, 42, 115-121

494

495

496

497

498

499 
500

501

502

503

504

505

506

507 Figure Captions

508 Figure 1: Kolb learning cycle after Kolb (1984)

509 


\begin{tabular}{lll}
\hline Jump & \multicolumn{1}{c}{ Activity } & \multicolumn{1}{c}{ Timing } \\
\hline 1 & Clarify terms and concepts not readily comprehensible & Meeting 1 \\
2 & Define the problem & \\
3 & Analyze the problem and offer tentative explanations & \\
4 & Draw up an inventory of explanations & \\
5 & Formulate learning objectives & Between \\
\hline 6 & Collect further information through private study & Meetings \\
\hline 7 & & Meeting 2 \\
& problem. Reflect and consolidate learning & \\
\hline
\end{tabular}

511 Table 1: Maastricht model of PBL tutorials (after Gijselaers, 1995). 


\begin{tabular}{|c|c|c|c|c|}
\hline CRITERIA & $\begin{array}{l}\text { OZONE } \\
\text { STUDENTS }\end{array}$ & $\begin{array}{l}\text { OZONE } \\
\text { STAFF }\end{array}$ & OBS. SYS. STUDENTS & OBS. SYS STAFF \\
\hline $\begin{array}{l}\text { How well did students } \\
\text { understand the task? }\end{array}$ & 3.2 & 3.5 & 6.0 & 3.5 \\
\hline $\begin{array}{l}\text { How easily did groups quickly } \\
\text { focus on the key questions } \\
\text { required? }\end{array}$ & 3.5 & 2.3 & $4 \cdot 3$ & 2.5 \\
\hline $\begin{array}{l}\text { Was the activity a good } \\
\text { simulation of a 'real-world' } \\
\text { case }\end{array}$ & $4 \cdot 4$ & 6.3 & 4.7 & $3 \cdot 5$ \\
\hline $\begin{array}{l}\text { Did you anticipate the activity } \\
\text { would improve your specific } \\
\text { subject understanding? }\end{array}$ & 3.7 & 5.0 & 4.7 & $3 \cdot 5$ \\
\hline $\begin{array}{l}\text { How well did students engage } \\
\text { with specific reflective } \\
\text { activity }\end{array}$ & 2.9 & 2.7 & 2.0 & 1.5 \\
\hline $\begin{array}{l}\text { Was all the information } \\
\text { required provided to you in } \\
\text { the project text? }\end{array}$ & 3.9 & $5 \cdot 3$ & 7.7 & 1.5 \\
\hline $\begin{array}{l}\text { How much were staff used to } \\
\text { give subject specific } \\
\text { information }\end{array}$ & 2.8 & $5 \cdot 3$ & 1.7 & 4.5 \\
\hline $\begin{array}{l}\text { How much were staff used to } \\
\text { give generic skills information }\end{array}$ & 4.9 & 6.8 & 1.7 & $4 \cdot 5$ \\
\hline $\begin{array}{l}\text { Did comparison with other } \\
\text { groups/students help } \\
\text { students to reflect on their } \\
\text { work? }\end{array}$ & 3.0 & 6.3 & $N / A$ & 1.0 \\
\hline $\begin{array}{l}\text { Did reflection help students } \\
\text { improve their understanding? }\end{array}$ & $5 \cdot 3$ & $4 \cdot 7$ & $\mathrm{~N} / \mathrm{A}$ & 6.0 \\
\hline $\begin{array}{l}\text { Did students agree with the } \\
\text { staff assessment? }\end{array}$ & 2.8 & N/A & $N / A$ & $N / A$ \\
\hline $\begin{array}{l}\text { Did the activity improve } \\
\text { students generic skills? }\end{array}$ & $\mathrm{N} / \mathrm{A}$ & 2.7 & N/A & 3.0 \\
\hline $\begin{array}{l}\text { Did the activity improve } \\
\text { students subject specific } \\
\text { skills? }\end{array}$ & $3 \cdot 7$ & 3.3 & N/A & 2.0 \\
\hline
\end{tabular}




\begin{tabular}{lcccc}
\hline $\begin{array}{l}\text { CRITERIA } \\
\text { STUDENTS }\end{array}$ & $\begin{array}{c}\text { OZONE } \\
\text { STAFF }\end{array}$ & OBS. SYS. STUDENTS & OBS. SYS STAFF \\
$\begin{array}{l}\text { Did you prefer the time } \\
\text { constraint in the } \mathrm{O}_{3} \text { activity } \\
\text { to the open-ended Obs. Sys. } \\
\text { activity? }\end{array}$ & N/A & N/A & 3.0 & N/A \\
$\begin{array}{l}\text { Did you prefer working on } \\
\text { your own in the Obs. Sys. } \\
\text { activity rather than in a team } \\
\text { in the O3 activity? }\end{array}$ & N/A & N/A & 5.0 & \\
$\begin{array}{l}\text { The Obs. Sys. Activity } \\
\text { improved my subject specific } \\
\text { knowledge more than the O3 } \\
\text { activity? }\end{array}$ & N/A & N/A & & N/A \\
$\begin{array}{l}\text { The Obs. Sys. Activity was at } \\
\text { a higher educational level } \\
\text { than the O3 activity? }\end{array}$ & N/A & & & \\
\end{tabular}

514 Table 2: Results of student survey of PBL activities following implementation in year 1

515 (2009). Marks are awarded by participants on a scale of 1-10 with 1 being the highest

516 mark. N/A means a question was not asked to gain this information. Statistics are based

517 on 18 student surveys and 4 staff surveys for the ozonesonde activity and 3 student

518 surveys and 2 staff surveys for the observing system activity. 


\begin{tabular}{|c|c|c|c|c|}
\hline CRITERIA & $\begin{array}{l}\text { OZONE } \\
\text { STUDENTS }\end{array}$ & $\begin{array}{l}\text { OZONE } \\
\text { STAFF }\end{array}$ & OBS. SYS. STUDENTS & OBS. SYS STAFF \\
\hline $\begin{array}{l}\text { How well did students } \\
\text { understand the task? }\end{array}$ & 3.2 & 4.0 & 3.2 & 3.0 \\
\hline $\begin{array}{l}\text { How easily did groups } \\
\text { quickly focus on the key } \\
\text { questions required? }\end{array}$ & 4.2 & 3.0 & 2.6 & 3.0 \\
\hline $\begin{array}{l}\text { Was the activity a good } \\
\text { simulation of a 'real-world' } \\
\text { case }\end{array}$ & 4.2 & 4.7 & 2.4 & 2.5 \\
\hline $\begin{array}{l}\text { Did you anticipate the } \\
\text { activity would improve } \\
\text { your specific subject } \\
\text { understanding? }\end{array}$ & 3.7 & 2.3 & 1.6 & 2.0 \\
\hline $\begin{array}{l}\text { How well did students } \\
\text { engage with specific } \\
\text { reflective activity }\end{array}$ & 3.4 & 3.7 & 1.2 & 2.0 \\
\hline $\begin{array}{l}\text { Was all the information } \\
\text { required provided to you } \\
\text { in the project text? }\end{array}$ & $3 \cdot 5$ & $3 \cdot 5$ & 2.8 & 2.5 \\
\hline $\begin{array}{l}\text { How much were staff used } \\
\text { to give subject specific } \\
\text { information }\end{array}$ & 2.2 & 6.7 & 1.4 & $5 \cdot 5$ \\
\hline $\begin{array}{l}\text { How much were staff used } \\
\text { to give generic skills } \\
\text { information }\end{array}$ & 3.8 & 4.7 & 3.4 & 4.5 \\
\hline $\begin{array}{l}\text { Did comparison with other } \\
\text { groups/students help } \\
\text { students to reflect on their } \\
\text { work? }\end{array}$ & 2.3 & 2.5 & N/A & 2.5 \\
\hline $\begin{array}{l}\text { Did reflection help } \\
\text { students improve their } \\
\text { understanding? }\end{array}$ & 2.8 & $3 \cdot 5$ & $\mathrm{~N} / \mathrm{A}$ & 4.5 \\
\hline $\begin{array}{l}\text { Did students agree with } \\
\text { the staff assessment? }\end{array}$ & 3.6 & N/A & N/A & N/A \\
\hline $\begin{array}{l}\text { Did the activity improve } \\
\text { students generic skills? }\end{array}$ & N/A & 3.0 & N/A & 3.5 \\
\hline $\begin{array}{l}\text { Did the activity improve } \\
\text { students subject specific } \\
\text { skills? }\end{array}$ & 2.6 & $3 \cdot 3$ & N/A & 3.5 \\
\hline
\end{tabular}




\begin{tabular}{|c|c|c|c|c|}
\hline CRITERIA & $\begin{array}{l}\text { OZONE } \\
\text { STUDENTS }\end{array}$ & $\begin{array}{l}\text { OZONE } \\
\text { STAFF }\end{array}$ & OBS. SYS. STUDENTS & OBS. SYS STAFF \\
\hline $\begin{array}{l}\text { Did you prefer the time } \\
\text { constraint in the } \mathrm{O}_{3} \\
\text { activity to the open-ended } \\
\text { Obs. Sys. activity? }\end{array}$ & N/A & $\mathrm{N} / \mathrm{A}$ & 6.8 & $\mathrm{~N} / \mathrm{A}$ \\
\hline $\begin{array}{l}\text { Did you prefer working on } \\
\text { your own in the Obs. Sys. } \\
\text { activity rather than in a } \\
\text { team in the } \mathrm{O}_{3} \text { activity? }\end{array}$ & N/A & N/A & 3.6 & $\mathrm{~N} / \mathrm{A}$ \\
\hline $\begin{array}{l}\text { The Obs. Sys. Activity } \\
\text { improved my subject } \\
\text { specific knowledge more } \\
\text { than the } \mathrm{O}_{3} \text { activity? }\end{array}$ & N/A & N/A & $3 \cdot 4$ & $\mathrm{~N} / \mathrm{A}$ \\
\hline $\begin{array}{l}\text { The Obs. Sys. Activity was } \\
\text { at a higher educational } \\
\text { level than the } \mathrm{O}_{3} \text { activity? }\end{array}$ & N/A & $\mathrm{N} / \mathrm{A}$ & 3.6 & $\mathrm{~N} / \mathrm{A}$ \\
\hline
\end{tabular}

521 Table 3: Results of student survey of PBL activities following implementation in year 1

522 (2010). Marks are awarded by participants on a scale of 1-10 with 1 being the highest

523 mark. N/A means a question was not asked to gain this information. Statistics are based

524 on 21 student surveys and 3 staff surveys for the ozonesonde activity and 5 student

525 surveys and 2 staff surveys for the observing system activity. 
Concrete experience

Active experimentation

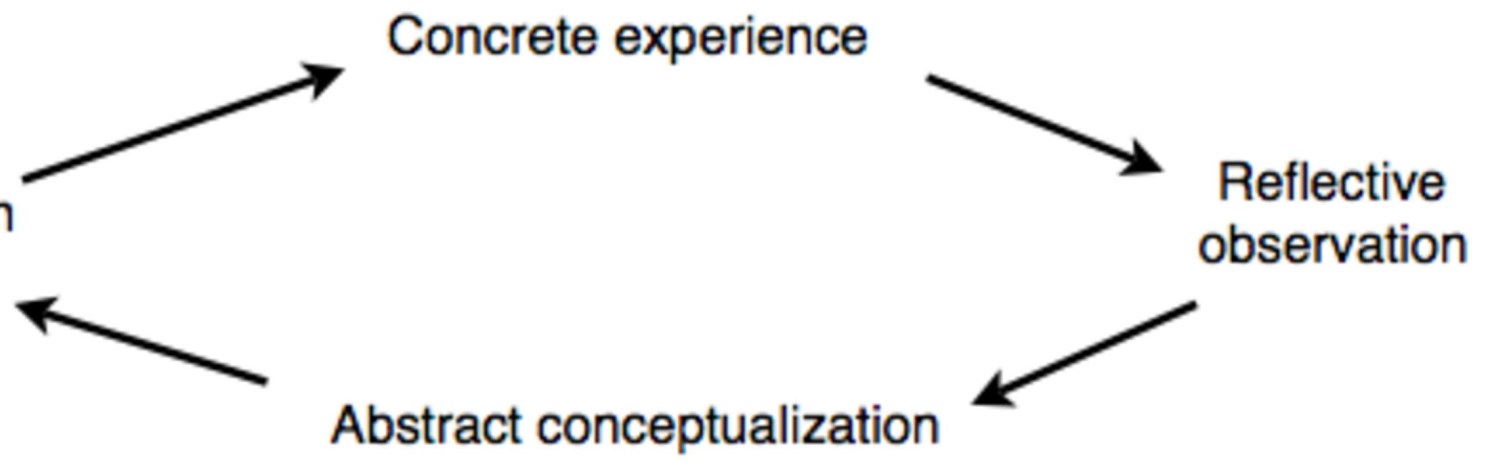

